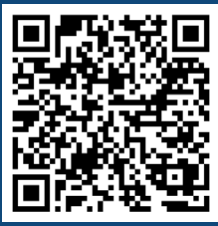

Keywords:

Network analysis

Bibliometric analysis

Ostrom's systemic approach

Forest management

Forest governance

Historic: Received 08/08/2019 Accepted 01/10/2019

Correspondence: joaopromanelli@hotmail.com
João Paulo Romanelli'+, Raquel Stucchi Boschila

\section{THE LEGACY OF ELINOR OSTROM ON COMMON FORESTS RESEARCH ASSESSED THROUGH BIBLIOMETRIC ANALYSIS}

ROMANELLI, J. P.; BOSCHI, R. S.The legacy of Elinor Ostrom on common forests research assessed through bibliometric analysis. CERNE, v. 25, n. 4, p.332-346, 2019.

\section{HIGHLIGHTS}

Ostrom's principles were used by several environmental researchers worldwide.

Regarding governance outcomes, certain types of rules are more important than others.

Community-based studies should be conducted using larger samples.

Future studies should adopt ecological thinking in the structure of SES.

\section{ABSTRACT}

A bibliometric analysis was performed to evaluate the research on common forest management that were influenced by the seminal work of Elinor Ostrom (Governing the Commons), from 1990 to 20I8. This analysis was based on the online database of the Science Citation Index Expanded - Web of Science $(\mathcal{C}$. Six main aspects of the retrieved publications were evaluated: (I) publication years; (2) journals; (3) countries (or regions); (4) study approach type; (5) authors; and (6) keywords. This research topic has shown to be relevant all over the world. Authors from 34 different countries have been conducting studies based on Ostrom's theory. Researchers have addressed this research topic primarily through case studies (approximately $83 \%$ of the publications). Among the retrieved literature body, the USA, Ecuador, Slovenia, Tanzania and Bangladesh have presented more than two case studies. All retrieved publications were published in 16 different journals. "Forest Policy and Economics" and "Ecology \& Society" were the two most widely used journals to disseminate results. Around II 5 different author's expressions have been used as keywords to describe this subject. The main concepts addressed by the authors were: "Forest Governance"; "Institutional Analysis and Development Framework"; "Property Rights"; "Socio-ecological Systems"; "Community-based Forest Management"; "Co-management"; "Design Principles"; "Institutions"; "Common-pool Resource" and; "Sustainability". Overall, this framework proved to be effective to evaluate the research trends, conflicting results and knowledge gaps surrounding the theme, and to contribute with researchers and governments on management and decision-making on this domain. 


\section{INTRODUCTION}

Forests are widely recognized as important providers of ecosystem services (POHJANMIES et al., 2017). These services include food production, wood products, and fuel; the conservation of water quality and regulation; nutrient retention; carbon sequestration; climate regulation; ecotourism and socio-cultural values (MA, 2005; MARTÍN-LÓPEZ et al., 2016). Forests also provide habitat for many species of economic interest and maintain the biodiversity, structure, and functioning of biological systems (BOWEN et al., 2007; VESPA et al., 2018). In general, forest ecosystems play an important role in protecting the very landscapes that humans depend on (LOPEZ; MORAN, 20I6).

The sustainability of forest ecosystems, on the other hand, can be influenced by several factors, such as the expansion of agricultural cropping areas and urbanization, the adverse effects of climate change and forest management (LOPEZ; MORAN, 2016). Forests and their transformations, as well as ways of sustaining them, are some of the main research topics of Elinor Ostrom (1990). The author investigated the management of common forests through a series of studies in organizations on which she was founder and co-founder (LOPEZ; MORAN, 2016). In her seminal book (Governing the Commons), Ostrom investigated different types of common resources, including forests, and concluded, unlike Hardin (1968), that some local communities were able to manage their forest resources sustainably (ROY et al., 20 I2; ANDERSSON et al., 20I4).

Her achievements have nourished a new and growing body of literature on the management of common forests around the world. In addition to the importance of climate issues, population growth and the need for a new model of sustainable management, scientific publications on forest subjects have been boosted (AZNAR-SÁNCHEZ et al., 2018). Hence, the number of journals on the theme has also increased (MALESIOS; ARABATZIS, 20I2). Despite this spreading of the subject, a lack of studies (specifically) dedicated to the analysis of the dynamics and systematic organization of the publications on common forests management under the bias of the Ostrom's systemic concepts was evidenced. This study aims to fill this knowledge gap through a bibliometric analysis. Studies with this characteristic can provide new insights on forests management research and point to its access points.

Analysis of research trends through bibliometric studies has received considerable attention in recent decades. Bibliometric research provides information on changes and trends in the course and content of scientific research (LIU et al., 20II; ZHANG et al., 2017). Bibliometric techniques make use of statistical and mathematical tools to measure researchers' contributions to the literature (ŞENEL; DEMIR, 20I8). Moreover, bibliometric studies can be used in specific fields of study or even in whole disciplines (BULLOCK; LAWLER, 20I5). This field of research is relatively recent (ŞENEL et al., 2017). The precursor of this methodology was Garfield in the mid-twentieth century (HUANG et al., 20I4).

Bibliometric analysis has already been used in several fields of science (VAN ECK et al., 2010), including studies concerning forest ecosystems (AZNARSÁNCHEZ et al., 2018). In Aleixandre-Benavent et al. (2018), for example, the authors have analyzed trends in global deforestation research; and Song and Zhao (2013) have used this resource to analyze research on forest ecology. Romanelli et al. (2018) also have used bibliometrics to analyze research on ecological restoration practice worldwide.

Considering the importance of forest ecosystems for global environmental sustainability and the advantages of bibliometric analysis to systematize metadata information, it is presented in this study an overview of research that was influenced by Ostrom's legacy after the publication of Governing the Commons in 1990. Information presented in this paper includes studies on the management of common forests in the time period 1990-2018 (Web of Science database); of particular interest to researchers and practitioners involved with forest management to identify the main topics already addressed and recent research status within this field of knowledge. The primary aims of this paper are: (I) examine the main topics and concepts addressed by the retrieved literature body; (2) summarily present the content of publications, highlighting the countries (or regions) where the studies were conducted; (3) present the main journals, the most influential authors, the years of publication, the number of citations and the type of approach of the studies (case studies and non case studies).

\section{MATERIAL AND METHODS}

Bibliometric indicators were developed considering the bibliographic data of publications indexed in the online database of the Science Citation Index Expanded (SCI-E) - ISC - Clarivate Analytics - Web of Science $($ C (WoS) (https://webofknowledge. $\mathrm{com} /$ ). The database is often used in the development of academic and bibliometric studies (AZEVEDO et al., 2005; BOANARES; AZEVEDO, 20I4; ROMANELLI et al., 20I8). It was used two sets of data, which were 
retrieved by different search strategies in WoS. These searches were designated as first search and second search (Figure I). Only articles and reviews were considered in this analysis since they represent the majority of documents with complete research results (FU et al., 2013; ROMANELLI et al., 2018). Datasets were downloaded on February, 2019.

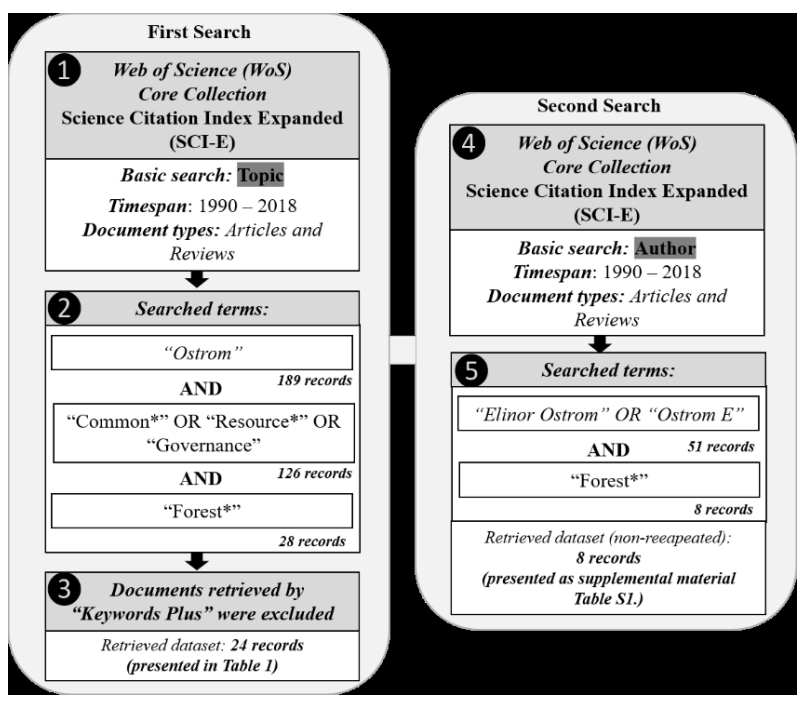

FIGURE I Synthesis of the employed methodology.

At the first search, the selected terms were applied to the Topic field, which searches for publications through the title, abstract, keywords of the authors and Keywords Plus (BOUDRY et al., 2018). Keywords Plus augmented the title-word and author keyword indexing by supplying additional search terms extracted from the titles of article references on WoS (GARFIELD, 1990). Keywords Plus has been effective in research concerning the knowledge structure of scientific fields in terms of bibliometric analysis (ZHANG et al., 2016; FU et al., 20I8), but it may also bring some noise to results. Publications retrieved through Keywords Plus were analyzed in detail and the publications that moved away from the central theme were excluded from the analysis. The terms used in the first search were combined to retrieve the publications that addressed the theme of common forests and also because the term explicitly refers to the Ostrom's work. In this way, it was used the term "Ostrom" (instead of "Elinor Ostrom") in the first row of search because it is more comprehensive and almost all publications refer to the author only by using the last name. In the second row, it was used the terms "Common*" OR "Resource*" OR "Governance*" to refer to the book entitled as Governing the Commons. The asterisk is a wildcard character for any letter or group of letters after the main word (PALENCIA et al.,
2009). Lastly, in the third row we use the term "Forest*" to finalize the selection of the publications. The selected records were later separated between case studies and non-case studies.

In the second search the selected terms were applied to the "Author" field to retrieve the publications of Elinor Ostrom on common forests, wich has not been considered in the discussion of this study. The terms "Elinor Ostrom" OR "Ostrom E" AND "Forest*" were used, retrieving 8 records. Publications retrieved by the second search are presented as supplementary material (Table S.I.).

The final dataset represents a sample of 24 retrieved publication. Bibliometric indicators analyzed were: (i) publication years; (ii) journals; (iii) countries (or regions); (iv) type of study approach; (v) authors; and (vi) keywords. All analyses were performed using the "Analyzing Results" tool provided by the database (WoS) with MS Excel support (v. 2016) to perform calculations and to draw indicator graphs. The bibliometric mapping was developed through VOSviewer (software version I.6.6; www.vosviewer.com), considering the criterion of co-occurrence of keywords.

\section{RESULTS AND DISCUSSION}

\section{Keywords analysis}

To investigate the most common search topics among the selected publications, an author's keywords evaluation was performed. Keywords analysis provide a synthesis of a research topic (GARFIELD, 1990), and present important terms that were addressed by the authors (BOUDRY et al., 20I8). The terms considered as keywords can be used to analyze the trends of a research area and to show the existing gaps (GUO et al., 2016). In this analysis, repeated words or terms, and meaningless words (also called stopwords) were not taken into account (Fig. 2). It is estimated that 115 author's expressions have been used to describe the retrieved bibliometric sample of this study, which may suggest the wide diversity of subjects covered within this domain (CHUANG et al., 2007). Keywords with at least two occurrences among the selected publications (Fig. 2) are presented and discussed under the bias of the common forest resources.

\section{Common-pool resources (CPR)}

Common-pool resources (CPR) are defined as a natural or artificial resources large enough to not exclude multiple users. They are systems that generate finite quantities of resource units, so that one person's 
social-ecological systems

forest governance

institutional analysis and dev

community-based forest managem

vOSviewer

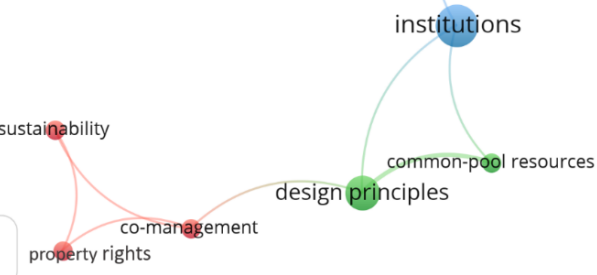

FIGURE 2 Network visualization map for the main author's keywords on "Ostrom" and "Forest commons" research. The size of the node is proportional to the number of citations as well as the thickness of the edges between nodes. The colors indicate which cluster of subjects the item belongs to. The absence of links between items refers to the non-co-occurrence of the terms in the retrieved publications.

use subtracts the amount of resource units available to others (LOPEZ; MORAN, 20I6). Communal forests are classified as CPR according to Ostrom (1994) for two main reasons: i) the exclusion of users through the development of institutions is difficult and expensive; and ii) when individuals subtract these resources through use (in general), fewer resources remain available to the rest of the group (ÁLLO; LAUREIRO, 20I6), which has been designated by some authors as "rival". When resource units are highly valued and many actors benefit from the appropriation for consumption, exchange, or as a factor in the production process, appropriations made by an individual are likely to create negative externalities for other users (OSTROM, 1994).

As described by Gordon (1954), Olson (1965) and Hardin (1968), it is assumed that when individuals use common resources together, each individual is driven to withdraw many units (and/or invest less in maintenance resource), which would not be ideal from a group point of view. Individuals jointly using a common resource are presumed to face a tragic situation of maintaining this resource. However, it is important to consider the assumptions under which these predictions are made (ALLÓ; LAUREIRO, 2016).

\section{Forest governance}

Around the world, different types of forest governance are used to manage forests. There are a number of strategies for managing them, such as: national parks (for the purpose of preservation), private landowners, rural communities (which have demonstrated the ability to create administrative rules) and, in other situations, forests may also be coadministered by different actors. In this sense, it is necessary to identify the existing institutions that manage forests to understand their social, ecological, political and economic performance (LOPEZ; MORAN, 2016).

Ostrom investigated forests through a series of organizations at Indiana University: the Center for the Study of Institutions, Population and Environmental Change (CIPEC), the International Forest Resources and Institutions Program (IFRI) and the Workshop on Political Theory and Policy Analysis. Research conducted by CIPEC and IFRI has shown that to have good forest governance, regardless of the type of institution that manages the forest, it is necessary to have a common goal and a shared approach, respected among different stakeholders, in addition to the direct forest users (LOPEZ; MORAN, 2016).

\section{Institutions}

Institutions, as defined by Ostrom (1990), are formal and informal rules in use; and determine what people can do, must do or cannot do in specific situations. Also, in Ostrom (1990), the author postulated a set of eight general design principles that seemed to characterize the effectiveness of these multiple types of rules and sets of rules. In Crawford and Ostrom (1995), the authors define institutions as regulators of human actions, constituted and reconstituted by rules, norms and shared strategies. Finally, in Hess and Ostrom (2007) the authors bring the concept of institutions as: formal and informal rules that are understood and used by a given community. Ostrom is considered a representative of the New Institutional Economy (ŁAPNIEWSKA, 2016).

Institutional analysis and development (IAD) framework

Ostrom's Institutional Analysis and Development (IAD) framework has been widely used in research to study the local management of common resources, such as forests (BENSON et al., 20 I 3; CLEMENT; AMEZAGA, 2013). The framework is one of many approaches to conducting institutional analysis (OSTROM, 1986; OSTROM, 1990). Futhermore, this framework has been widely used in scientific research to investigate the planning and management of forests around the world (FLEISCHMAN, 20I5). From the IAD framework it is possible to obtain a guidance on the main insights of institutional, technical and participatory aspects of 
collective interventions, or the common problem and its resulting effects (NIGUSSIE et al., 20I8).

\section{Community-based forest management}

The failure of centralized approaches to natural resource management has propelled the search for a viable and sustainable alternative approach to achieving sustainable management (NABANE; MATZKE, 1997; MILUPI et al., 2017). Thus, the approach to property rights granted to local communities to manage natural resources became common in the 1960s, which was recognized as Community-based Natural Resource Management (CBNRM). This type of management was aimed to create conditions where most members of the community would benefit from the sustainable use and management of natural resources. According to the same author, this should occur through a participatory approach from the "bottom-up", considering several principles, which include: meeting basic needs of local populations, local and non-state control, delivery and equitable sharing of benefits and resources and commitment of members of the community and institutions for the management and conservation of natural resources (MILUPI et al., 2017). Ostrom identified the existence of a set of "design principles" that were common to the communities that are self-governed in a sustainable way (LOPEZ; MORAN, 2016). The author described this phenomenon as the "emergence" of collective action to manage the common resource. Community-based conservation promotes the idea that long-term conservation success required engagement and provision of benefits to local communities (BROOKS et al., 20I3; BANNETT; DEARDEN, 20I4; GURNEY et al., 2016).

\section{Co-management}

Many governments have adopted the forest comanagement framework as a process of decentralization and deconcentration of management; usually, where costs and benefits are shared with communities within a defined structure of property rights (BALAND; PLATTEAU, 1996). Empirical research has shown that comanagement succeeds when there are defined property rights to ensure an equitable distribution of resources and benefits (BEHERA, 2009; SHAHABUDDIN; RAO, 2010). Notably, Plummer and Fitzgibbon (2004) define co-management as "the distribution of rights and responsibilities belonging to a particular resource".

The scientific literature on forest sustainability and property rights presents co-management as a key instrument for sustainable forest management
(PLUMMER; FITZGIBBON, 2004; JUMBE; ANGELSEN, 2007). However, co-management (as a model of cooperative management) does not always present achieve results, even though the different forest communities are under the same physical environment and management institutions (ZHU et al., 20 I4). In China, for example, some co-management initiatives have resulted in economic progress and social development, while others have stopped progressing at the beginning of project implementation (TING et al., 20I0; CHEN et al., 20I2; TING et al., 20I I). These contradictory cases show that more studies about this issue are demanded, also point out the need to investigate other management factors in the success or failure of co-management of forest resources.

Property rights

Property rights can be understood as all kinds of relationships between actors and objects (SCHLAGER; OSTROM, 1992; SIKOR et al., 2017). The right to access, use, manage, protect and transfer of resources composes the individual or community property rights package (SCHLAGER; OSTROM, 1992). The focus on property rights, as they are applied in practice, provides an important "bottom-up" perspective on governance of common resources that is complementary to the relationships centered on different government actors (AGRAWAL; RIBOT, 1999; SIKOR et al., 2017).

In the case of common forests, the policy framework of each country can establish co-management systems in which government partially transfers the rights over these resources to local users, but retains a certain supervisory authority (GUARIGUATA, 20I7). In these co-management schemes, governments need to provide property rights that define who has the rights and responsibilities to manage and encourage sustainable management practices (CRONKLETON et al., 20I2; CRONKLETON et al., 20I3; HLAING et al., 20I3). While granting property rights is an important path for maintaining common resources, national and local governments still need to monitor them to ensure the involvement of all stakeholders (HLAING et al., 20I3; GUARIGUATA, 2017).

\section{Design principles (DP)}

Ostrom defined Design Principles (DP) as "an essential element or condition that helps explain the institutions' success in sustaining common-pool resources (CPR) and gaining generation-after-generation conformity of appropriators to the rules in use" 
(OSTROM, 2010). The author argues that the expression "design principles", which means, literally, a collection of terms, may have confused many readers, and that perhaps the expression "best practices" might better reflect the idea of rules or the structure of institutions (OSTROM, 20I0; HOLDEN; TILAHUN, 20I8).

Ostrom's eight design principles for commonpool resource (CPR) institutions proved to be influential (SAUNDERS, 20I4). Her studies are popular because there are many empírical examples drawn from institutions around the world and her work presents an alternative to the pessimistic prediction that man can not cooperate effectively with natural resource management (SAUNDERS, 20I4; TILAHUN, 20I8). The Ostrom's Design Principles were first listed in her book (OSTROM, 1990) and later refined in Ostrom (2010).

Social-ecological systems (SES)

All the resources used by humans are embedded in complex social and ecological systems (SES). SES are composed of multiple subsystems and internal variables within these multi-level subsystems that are analogous to the biological hierarchies of living systems (VON BERTALANFFY, 1968; PENNISI, 2003; OSTROM, 2009). In a complex SES, subsystems such as: resource system, resource units, users, and governance systems are relatively separable but interact with each other and provide feedback to affect subsystems and their compartments as well as other larger and smaller SES (OSTROM, 1990). Structurally, SES resemble von Bertalanffy's (1968) systemic assumptions and other approaches updated under this author's precepts (DRACK, 2009; DRACK; WOLKENHAUER, 20II).

While it is recognized that science must increase its efforts to sustain SES, the ecological and social sciences have developed independently and do not easily combine to facilitate sustainability promoting process (OSTROM et al., 2002). In addition, scholars tend to develop simple theoretical models to analyze aspects of resource problems and prescribe universal solutions (OSTROM, 2009).

\section{Sustainability}

In 1987, the World Commission for Environment and Development (WCED) published its seminal report, Our Common Future, which raised up the question about discussion on how the world population should engage in sustainable development, including how they can address the global resource systems, or "commons" (WCDE, 1987; OSTROM, 2008). In this report, the commission noted that: "Humanity has the capacity to make development sustainable - to ensure that it meets the needs of the present without compromising the ability of future generations to meet their own needs".

Although many policy analysts think that private ownership of a common resource is a guaranteed method for sustainability, it can fail to assure long-term protection. Proof of this is that much of deforestation occurs when farmers promote the clearing of their private land for agricultural purposes. Therefore, effective monitoring of employees and users is an essential ingredient of sustainable CPR institutions (OSTROM, 2008).

Scholarship on forest commons certainly examined how commons resources act in relation to their institutional arrangements to achieve desired societal goals, such as conservation, sustainability, and resource condition improvements (AGRAWAL 1996; AGRAWAL, 2007). Notably, some scholars have pointed to the interdependence of different forms of property rights and institutional arrangements and implicitly questioned whether the terms private, common, and state are distinct domains of governance or complementary systems and are, therefore, best viewed as mixed forms (ANTINORI; BRAY 2005; BRAY et al., 2006; GRAFTON, 2000). Additional comparative research involving different governance systems attempting to identify their specific strengths under specific circumstances would certainly be welcomed by forest patrimony scholars (AGRAWAL, 2007).

\section{Publications contents}

In general, all publications retrieved by bibliometric analysis were published in 16 different journals (Table I). Most of these journals (about 75\%); however, only published one paper within the theme addressed by this research. This research topic has proved to be relevant in various parts of the world, involving authors from 34 different countries. Most part of the publications was conducted from case studies. Publications that did not involve case studies were concerned with presenting broader approaches and discussing Ostrom's concepts from a more general perspective. The main research topics investigated by the retrieved publications in the first search (Table 2) are presented below and discussed in detail under the bias of the common forests' management, and according to the precepts of Ostrom and other authors that were influenced by her studies.

\section{Case Studies}

In the context of the publications that were conducted from case studies, the authors Guariguata 
TABLE I Retrieved publications by the first search ranked by publication years; followed by title, authors and journal.

\begin{tabular}{|c|c|c|c|}
\hline Year & Title & Authors & Journal \\
\hline 2017 & $\begin{array}{l}\text { Revisiting the 'cornerstone of Amazonian conservation': a socioecological assessment of } \\
\text { Brazil nut exploitation }\end{array}$ & Guariguata et al. & Biodiversity and Conservation \\
\hline 2017 & Forest recreation as a governance problem: four case studies from Switzerland & $\begin{array}{l}\text { Wilkes-Allemann } \\
\text { et al. }\end{array}$ & $\begin{array}{l}\text { European Journal of Forest } \\
\text { Research }\end{array}$ \\
\hline 2017 & A review of community-based natural resource management & Milupi et al. & $\begin{array}{l}\text { Applied Ecology and } \\
\text { Environmental Research }\end{array}$ \\
\hline 2016 & $\begin{array}{l}\text { Evaluating the fulfillment of the principles of collective action in practice: A case study } \\
\text { from Galicia (NW Spain) }\end{array}$ & Alló and Loureiro & Forest Policy and Economics \\
\hline 2016 & $\begin{array}{l}\text { REDD plus implementation in the Ecuadorian Amazon: Why land configuration and } \\
\text { common-pool resources management matter }\end{array}$ & Loaiza et al. & Forest Policy and Economics \\
\hline 2016 & The legacy of Elinor Ostrom and its relevance to issues of forest conservation & Lopez and Moran & $\begin{array}{c}\text { Current Opinion In } \\
\text { Environmental Sustainability }\end{array}$ \\
\hline 2016 & $\begin{array}{l}\text { Building local institutions for national conservation programs: lessons for developing } \\
\text { Reducing Emissions from Deforestation and Forest Degradation (REDD plus) programs }\end{array}$ & Collen et al. & Ecology and Society \\
\hline 2015 & $\begin{array}{l}\text { Institutional factors and opportunities for adapting European forest management to } \\
\text { climate change }\end{array}$ & Bouriaud et al. & $\begin{array}{l}\text { Regional Environmental } \\
\text { Change }\end{array}$ \\
\hline 2015 & From restitution to revival: A case of commons re-establishment and restitution in Slovenia & Premrl et al. & Forest Policy and Economics \\
\hline 2015 & $\begin{array}{l}\text { Disturbances, robustness and adaptation in forest commons: Comparative insights from } \\
\text { two cases in the Southeastern Alps }\end{array}$ & Gat & j Forest Policy and Ec \\
\hline 2015 & $\begin{array}{c}\text { Institutional Change and Institutional Performance Under Decentralized Forest } \\
\text { Management in Babati District, Tanzania }\end{array}$ & Babili et al. & Small-Scale Forestry \\
\hline 2015 & Putting the "E" in SES: unpacking the ecology in the Ostrom social-ecological system framework & Vogt et al. & Ecology and Society \\
\hline 2014 & Institutional diversity and local forest governance & Andersson et al. & Environmental Science \& Policy \\
\hline 2014 & Enhancing the Ostrom social-ecological system framework through formalization & Hinkel et al. & Ecology and Society \\
\hline 2014 & $\begin{array}{l}\text { Co-management implementation in forested national reserves: Contradicting cases } \\
\text { from China }\end{array}$ & Zhu et al. & Forest Policy and Economics \\
\hline 2013 & $\begin{array}{l}\text { Economics of the external and the extended orders of markets and politics and their } \\
\text { application in forestry }\end{array}$ & Deegen & Forest Policy and Economics \\
\hline 2013 & $\begin{array}{c}\text { Community perceptions of state forest ownership and management: A case study of the } \\
\text { Sundarbans Mangrove Forest in Bangladesh }\end{array}$ & Roy et al. & $\begin{array}{l}\text { Journal of Environmental } \\
\text { Management }\end{array}$ \\
\hline 2013 & Challenges for Community-Based Forest Management in the KoloAla Site Manompana & Urech et al. & Environmental Management \\
\hline 2012 & $\begin{array}{l}\text { A review of the role of property rights and forest policies in the management of the } \\
\text { Sundarbans Mangrove Forest in Bangladesh }\end{array}$ & Roy et al. & Forest Policy and Economics \\
\hline 2010 & A Review of Design Principles for Community-based Natural Resource Management & Cox et al. & Ecology and Society \\
\hline 2010 & $\begin{array}{l}\text { Disturbance, Response, and Persistence in Self-Organized Forested Communities: } \\
\text { Analysis of Robustness and Resilience in Five Communities in Southern Indiana }\end{array}$ & Fleischman et al. & Ecology and Society \\
\hline 2007 & $\begin{array}{c}\text { Design principles and common pool resource management: An institutional approach to } \\
\text { evaluating community management in semi-arid Tanzania }\end{array}$ & Quinn et al. & $\begin{array}{l}\text { Journal of Environmental } \\
\text { Management }\end{array}$ \\
\hline 2006 & Forest property rights under nationalized forest management in Bhutan & Dorji et al. & Environmental Conservation \\
\hline 2001 & $\begin{array}{l}\text { Organized participatory resource management: insights from community forestry } \\
\text { practices in India }\end{array}$ & Sekher & Forest Policy and Economics \\
\hline
\end{tabular}

et al. (2017) evaluated the socio-ecological system (SES) that characterizes the Brazil nut (Bertholletia excelsa), based on Ostrom's proposals for analysis of the conservation of the exploitation of this Amazonian forest resource. On this same research topic, Fleischman et al. (2010) developed an analytical framework for robustness analysis of socio-ecological systems (SES) over time. The authors have indicated through their empirical results some key variables that need to be at the center of theoretical work on the robustness of self-organized systems. In the study of Vogt et al. (2015), the authors intend to "unpack" the ecology in the structure of the socio-ecological system proposed by Ostrom. They argue that the framework early proposed by Ostrom has limited capacity to deal with the ecological complexity.
Alternatively, they suggest the development of an interdisciplinary structure for the study of SES.

Regarding the evaluation of the institutions, the IAD (Institutional Analysis and Development) framework proposed by Ostrom was applied by WilkesAllemann et al. (2017). The authors evaluated the forest recreation governance system using IAD framework and qualitative data based on cases and interviews. Bouriaud et al. (20I5), in turn, studied institutional factors and opportunities for adapting European forest management to climate change through the Ostrom's framework. The study presents the main factors that influence climate change adaptations when several levels of decision are being considered. 
TABLE 2 Retrieved publications by the first search classified in case studies (followed by the country/region where the study was conducted) and non-case studies.

\begin{tabular}{ccccc}
\hline \multicolumn{2}{c}{ Case Studies } & & Non-case studies \\
\hline Authors & Country/Region & Authors & Country/Region & Authors \\
\hline Guariguata et al., 20I7 & Brazil & Vogt et al., 2015 & United States & Lopez and Moran, 20I6 \\
\hline Wilkes-Allemann et al., 2017 & Switzerland & Andersson et al., 20I4 & Bolivia & Hinkel et al., 20I4 \\
\hline Milupi et al., 20I7 & Many countries & Zhu et al., 20I4 & China & Deegen, 20I3 \\
\hline Allo and Loureiro, 2016 & Spain & Roy et al., 20I3 & Bangladesh & Cox et al., 20I0 \\
\hline Loaiza et al., 2016 & Ecuador & Urech et al., 20I3 & Madagascar & - \\
\hline Collen et al., 2016 & Ecuador & Roy et al., 20I2 & Bangladesh & - \\
\hline Bouriaud et al., 2015 & European region & Fleischman et al., 20I0 & United States & - \\
\hline Premrl et al., 20I5 & Slovenia & Quinn et al., 2007 & Tanzania & - \\
\hline Gatto and Bogataj, 2015 & Slovenia and Italy & Dorji et al., 2006 & Bhutan & - \\
\hline Babili et al., 2015 & Tanzania & Sekher, 200I & India & - \\
\hline
\end{tabular}

Sekher (200I) studied organized resource management through insights from community forestry practices in India. The study explores how different local organizations affect the participatory management of common resources. The analysis was developed in accordance with Ostrom's DP and IAD structure. The author provides some broad organizational guidelines for development initiatives that require community involvement. Milupi et al. (2017) have also been concerned with reviewing the initiatives of CommunityBased Natural Resource Management (CBNRM) in different countries. They also used the Ostrom's design principles and objective measures to determine the success and failure cases of CBNRM. The challenges for community-based management in forest systems were also addressed by Urech et al. (20I3), where the authors studied some cases of forest management success in Madagascar and pointed out issues that still need to be solved in this management system. Regarding the co-management of forest resources, Zhu et al. (2014) presented contradictory cases in China. The authors argue that the capacity of the co-management mechanisms depend, among other factors, on the interests of local power actors, which are considered key factors in deciding the success of the implementation of that kind of management system.

The institutional approach performed by Quinn et al. (2007) considered the evaluation of community management in Tanzania through Ostrom's design principles. The authors emphasize the need for flexibility to deal with ecological uncertainty and support the view that these principles should not be used as a model to be imposed on resource management regimes. Bibili et al. (2015) have also studied institutional performance issues and argued that a structure of multiple institutional logics of action may be more capable of explaining change and institutional performance than institutionalism and Ostrom's design principles. Following the same approach, Andersson et al. (2014) evaluated institutional diversity and local forest governance. The authors argue that the more governance functions to help communities to decide how to organize, the more likely local forests are to become sustainable. Premrl et al. (20I5) used an up-todate version of Ostrom's design principles to assess the capacity of the legal framework to enable the robustness of historical institutions. The authors reveal that the rigid legal framework can affect efficiency in governance of common resources. Gatto and Bogataj (20I5) also used design principles to analyze disturbances, robustness, and adaptation in common forest management. The authors argue that forest commons are robust and adaptive socio-ecological systems, and point out the need for more research to better understand them.

In relation to property rights, Roy et al. (2013) addressed community perceptions about state forest ownership and management. The theoretical framework of Schlager and Ostrom was adopted to examine the role of potential property variations. The same authors presented in Roy et al. (20/2) a review of the role of property rights and forest policies in the management of common forests in Bangladesh. Dorji et al. (2006) studied forest property rights under nationalized forest management in Bhutan. Changes in forest property rights were also analyzed using Ostrom and Schlager's 'rights package' structure. As well as Roy et al. (2013), Dorji et al. (2006) argue that the successful management of forests requires a minimal difference between de jure policies and de facto practices.

Alló and Loureiro (2016), in turn, tested whether the Principles of Collective Action (PCA) postulated by Ostrom (1990) were being followed in a sample of communal forests or not. The authors found a negative relation between the PCA compliance and the number of forest fires. The authors Loaiza et al. (2016) and Collen et al. (2016) addressed REDD+ efforts in different contexts. They used Ostrom's Principles (1990) to assess land configuration and institutional arrangements for decision-making on the use of shared resources and their 
implications for REDD+ implementation. Collen et al. (2016) adopted an approach on building local institutions to national conservation programs by highlighting lessons for the development of REDD+ programs. To date, payment schemes for environmental services (PES), aimed at preserving threatened tropical forests (often denoted as "reduced emissions from deforestation" and "forest degradation" - REDD+ schemes) have shown positive impacts on forestry net economy. Further information on this domain can be obtained in Chomitz (2007), Porras et al. (20I3), and Strand (20I8).

\section{Non-case Studies}

In the context of publications classified as noncase studies, the authors Lopez and Moran (2016) addressed in their study the legacy of Elinor Ostrom in the issues related to the conservation, management and analysis of institutional diversity. The authors presented a broad overview of Ostrom's contributions to governance of common-pool resources and reported the author's contributions as founder and cofounder of programs and seminars. Hinkel et al. (20l4) sought to reinforce in their work the structure of the SES formulated by Ostrom through a formalization. They suggest that SES structures may include seven formal components: variables, concepts, assignment relationships, subsumption relationships, process relations, aggregation relationships, and evaluation metrics. These components are identified as generic. The insights obtained through the study can be used for the development of other SES structures.

Cox et al. (2010) conducted a review of design principles for community-based natural resource management. The authors analyzed 91 studies that explicitly or implicitly approached Ostrom's design principles to empirically evaluate which theoretical issues have arisen since its introduction. The authors argue that the principles are well supported empirically and propose a reformulation based on the common points found in the studies. Finally, Deegen (2013) presented the study about the economics of the external and the extended orders of markets and politics and their application in forestry. At first, the author systematizes existing economic theories and forestry models, such as Faustmann's approach and Ostrom's precepts, and other references. In the second step, the interrelationships between these approaches were studied. From this point of view, the author identifies some unanalyzed or less analyzed areas, which allows some comments for future research in forestry economics.

\section{General approach}

As a synthesis, it was possible to perceive that Ostrom's contributions were significant for issues related to management, forest conservation and understanding of institutional diversity. Ostrom has proven in her studies that self-governance is possible but that it is also influenced by several factors. In her studies, she emphasized the importance of multinational, multidisciplinary and comparative research between the social and natural sciences, and the inherent complexity of governance systems (LOPEZ; MORAN, 2016). Much of this insight became evident through the analysis of publications retrieved by bibliometric analysis.

Regarding common resources units, norms, social and even emotional relationships were listed as important factors to promote sustainable management (ALLÓ; LOUREIRO, 2016). Some types of resource units have been portrayed as being strongly influenced by the type and level of intervention to which they are subjected. Thus, promoting dialogue among different stakeholders in the management of common resources - which also includes buyers at the end of the value chain - can be instrumental in improving the equity and benefits of resource sharing (GUARIGUATA et al., 20I7). It has also been argued that the structure of Ostrom's SES is based on a solid empirical basis (HINKEL et al., 20I4). However, as it was initially constructed, this structure was portrayed as limited in its ability to understand joint socio-ecological outcomes and human-environmental problems. Fortunately, it is possible to include ecology in the structure of SES, as demonstrated by Vogt et al. (2015).

Ostrom's design principles have also been characterized in the literature as robust to the empirical test, but this does not mean that they are complete (COX et al., 2010). The design principles failed to fully explain some cases of management success, as demonstrated by Babili et al. (20I5). The incompleteness is the most relevant empirical critique of Ostrom's Design Principles (COX et al., 2010). In addition, variables such as the size of user groups, the different types of heterogeneity within or between user groups, and the type of government regime are also important issues that should be better addressed and discussed in this context (AGRAWAL, 2002).

The discussion on institutions and governance regimes was one of the main research topics that generated a number of conclusions by the authors. Ostrom's IAD framework, for example, proved to be effective in identifying and characterizing the planning and management of CPR, as in the case of forest recreation addressed by Wilkes-Allemann et al. (20I7). 
Other authors, however, argue that robust institutions, strongly suggested by Ostrom in the management of common resources, may in some cases be influenced by factors such as institutional and operational changes (BABILI et al., 20I5). Even institutions considered to be strong may weaken over time in the face of changes. The weakness of management regimes seems to be involved in the inability of these institutions to deal with changes (QUINN et al., 2007). Bouriaud et al. (2015) argued that adaptation to change is clearly institutionally directed through the ownership structure and the level of forest policy formation. In this context, location, ethnicity, and ecology were listed as important drivers of institutional arrangements (QUINN et al., 2007). Regulatory and sanctioning systems also represent important ingredients of effective forest governance arrangements (ANDERSSON et al., 20l4). Communities that exhibit successful cases of CPR management present a virtuous cycle in which group investment produces persistent and robust communities that are better suited to institutional disruptions (FLEISCHMAN et al., 20I0). Engaging diverse stakeholders in governance increases public commitment and robustness and fosters consensus to reduce conflicts (SEKHER, 200I; WILKES-ALLEMANN et al., 20I7).

Acommunity-based natural resource management program is possible when users of these resources are motivated to care for common resources (MILUPI et al., 2017). On the other hand, limited capacity for communitylevel concessions and exploration decisions may threaten sustainable governance of forest resources (LOAIZA et al., 2016). When there are contradictions and conflicts of interest between the different actors and the system of co-management institutions, the implementation of co-management may be terminated. A strictly top-down approach may also encounter land-user challenges and weaken this type of regime (ZHU et al., 20 I4; COLLEN et al., 2016). There is, therefore a need for flexible and continuous support for local communities in the development of robust local institutions (COLLEN et al., 2016). Different stakeholder groups should always be involved in the decision-making process (URECH et al., 20I3), and the incompatibility between de jure policies and de facto practices should be minimal if forests are to be managed successfully (DORJl et al., 2006).

Roy et al. (2012) argued that the effectiveness of the community management regime should be fostered through partnerships between state forest communities with a clearly implemented property rights regime. The provision of management incentives involves community participation through the allocation of appropriate property rights (ROY et al., 2013).
Rules that attribute property rights and how they are enforced among stakeholders are important elements of sustainable management (DORJl et al., 2006). When community property rights over the common resource and its users are not recognized it can easily lead to legal anticommons (PREMRL et al., 20I5). It is only through effective changes in the regime of property rights and policies that the sustainability of the common resource can be achieved (ROY et al., 2012).

Finally, one of the most frequent topics of insight on common forest management concerns the role of state management in mediating access to common forest resources and subsidizing self-governance regimes (DORJI et al., 2006; ROY et al., 2012; URECH et al., 20।3; GATTO; BOGATAJ, 20I5; PREMRL et al., 20I5; GUARIGUATA et al., 2017). As a political implication of this specific theme, it is important to consider the political objectives with local community practices (BABILI et al., 20I5) from an integrated approach, implying a collaborative strategy among all involved, not only within the community of users, but also between the community and the government (SEKHER, 200I).

\section{CONCLUSIONS}

The objective of this study was to retrieve and analyze the scientific publications indexed in the Web of Science (SCI-E database) that addressed the common forests research under the bias of the systemic concepts of Ostrom (Governing the Commons), through a bibliometric analysis. Information summarized in this paper presents the recent research status and experience of various authors in this field of knowledge, demonstrating the breadth and importance of this discipline in various parts of the world.

In general, this research topic has been shown to be relevant all over the world, covering 34 different countries. The USA, Ecuador, Slovenia, Tanzania, and Bangladesh have accumulated most studies among the retrieved publications. Most of the publications were characterized as case studies, where the different Ostrom's concepts were used to assess the sustainability of common forest resource management. Publications classified as non-case studies were characterized as literature reviews, which have dealt to synthesize, review and propose new concepts from Ostrom studies.

Most journals used to disseminate results have published only one paper within the theme. However, Forest Policy and Economics and Ecology \& Society have accumulated the most publications 
(about 50\%). According to the keywords analysis, the terms that represent the main subjects addressed by the authors are: "Forest Governance"; "Institutional Analysis and Development Framework"; Property Rights; Socio-ecological Systems; Community-based Forest Management; "Co-management"; "Design Principles"; Institutions; "Common-pool Resource" and; Sustainability.

Finally, based on the content analysis of the publications, it is suggested that future studies address the following aspects: $(I)$ the possibility that there are certain types of rules that are more important than others regarding governance outcomes; (2) in the context of self-governance, consider finding new ways for national governments to support forest user communities in their local efforts to manage forest resources efficiently (Andersson et al., 20l4); (3) it is recommended that community-based natural resource management studies be conducted with larger samples using different techniques to increase understanding of the multiple factors needed to achieve these initiatives effectively and sustainably (MILUPI et al., 20I7); (4) stimulate studies that seek to adopt ecological thinking in the structure of SES (VOGT et al., 20I5). Moreover, it is argued in the governance literature that it is not so much the rule itself that matters, but how it fits into specific local biophysical, socioeconomic, and cultural circumstances (BASURTO; COLEMAN, 2010; ANDERSSON et al., 2014). Cox et al. (2010) reinforce that much work remains to be done to improve the sophistication of common-pool resource case studies to understand how institutional variables interact with these biophysical variables to produce results. Additionally, to be able to propose more general considerations about the management of common forests, more empirical research is needed, considering different spatial and temporal scales (SEKHER, 200I; VOGT et al., 20I5; WILKES-ALLEMANN et al., 2017).

\section{REFERENCES}

AGRAWAL, A. Forests, Governance, and Sustainability: Common Property Theory and its Contributions. International Journal of the Commons, v. I, n. I, p. III, 2007.

AGRAWAL, A. The community vs. the market and the state: Forest use inUttarakhand in the Indian Himalayas. Journal of Agricultural and Environmental Ethics, v. 9, n. I, p. I-I5, 1996.

AGRAWAL, A; RIBOT, J. Accountability in Decentralization: A Framework with South Asian and West African Cases. The Journal of Developing Areas, v. 33, n. 4, pp. 473-502, 1999.

ALEIXANDRE-BENAVENT, R.; ALEIXANDRE-TUDÓ, J. L.; CASTELLÓ-COGOLLOS, L.; ALEIXANDRE, J. L. Trends in global research in deforestation. A bibliometric analysis. Land Use Policy, v. 72, p. 293-302, 2018.
ALLÓ, M.; LOUREIRO, M. L. Evaluating the fulfillment of the principles of collective action in practice: A case study from Galicia (NW Spain). Forest Policy and Economics, v. 73, p. I-9, 2016.

ANDERSSON, K.; BENAVIDES, J. P.; LEÓN, R. Institutional diversity and local forest governance. Environmental Science \& Policy, v. 36, p. 6I-72, 2014.

ANTINORI, C.; BRAY, D. B. Community forest enterprises as entrepreneurial Firms: Economic and institutional perspectives from Mexico. World Development, v. 33, n. 9, p. I529-I543, 2005.

AZEVEDO, P. G.; MESQUITA, F. O.; YOUNG, R. J. Fishing for gaps in science: a bibliographic analysis of Brazilian freshwater ichthyology from 1986 to 2005. Journal of Fish Biology, v. 76, n. 9, p. 2177-2193, 2010.

AZNAR-SÁNCHEZ, J.; BELMONTE-UREÑA, L.; LÓPEZSERRANO, M.; VELASCO-MUÑOZ, J. Forest Ecosystem Services: An Analysis of Worldwide Research. Forests, v. 9, n. 8 , p. $453,2018$.

BABILI, I. H.; MTALO, E.; KAJEMBE, G. C.; VAN DER WAL, H. Institutional Change and Institutional Performance Under Decentralized Forest Management in Babati District, Tanzania. Small-scale Forestry, v. I4, n. 3, p. 38I-400, 20 I5.

BALAND, J.M.; PLATTEAU. J.P. Halting Degradation of Natural Resources - Is There a Role for Rural Communities? Oxford: Clarendon Press, 1996. 276p.

BASURTO, X.; COLEMAN, E. Institutional and ecological interplay for successful self-governance of communitybased fisheries. Ecological Economics, v. 69, n. 5, p. 1094I 103, 2010.

BEHERA, B. Explaining the performance of state-community joint forest management in India. Ecological Economics, v. 69, n. I, p. 177-185, 2009.

BENNETT, N.J.; DEARDEN, P. Why local people do not support conservation: Community perceptions of marine protected area livelihood impacts, governance and management in Thailand. Marine Policy, v. 44, p. I07-I 16, 2014.

BENSON, D.; JORDAN, A.; COOK, H.; SMITH, L. Collaborative environmental governance: Are watershed partnerships swimming or are they sinking?. Land Use Policy, v. 30, n. I, p. 748-757, 2013.

BOANARES, D.; AZEVEDO, C. S. D. The use of nucleation techniques to restore the environment: a bibliometric analysis. Natureza \& Conservação, v. I2, n. 2, p. 93-98, 2014.

BOUDRY, C.; BAUDOUIN, C.; MOURIAUX, F. International publication trends in dry eye disease research: $A$ bibliometric analysis. The Ocular Surface, v. 16, n. I, p. |73-179, 2018. 
BOURIAUD, L.; MARZANO, M.; LEXER, M.; NICHIFOREL, L.; REYER, C.; TEMPERLI, C.; PELTOLA, H; ELKIN, C.; DUDUMAN, G.; TAYLOR, P.; BATHGATE, S.; BORGES, J.; CLERKX, S.; GARCIA-GONZALO, J.; GRACIA, C.; HENGEVELD, G.; KELLOMÄKI, S.; KOSTOV, G.; MAROSCHEK, M.; MUYS, B.; NABUURS, G.; NICOLL, B.; PALAHÍ, M.; RAMMER, W.; RAY, D.; SCHELHAAS, M.; SING, L.; TOMÉ, M.; ZELL, J.; HANEWINKEL, $M$. Institutional factors and opportunities for adapting European forest management to climate change. Regional Environmental Change, v. I5, n. 8, p. I595-I609, 2015.

BOWEN, M. E.; MCALPINE, C. A.; HOUSE, A. P.; SMITH, G. C. Regrowth forests on abandoned agricultural land: A review of their habitat values for recovering forest fauna. Biological Conservation, v. I40, n. 3-4, p. 273-296, 2007.

BRAY, D. B.; ANTINORI, C.; TORRES-ROJO, J. M. The Mexican model of community forest management: The role of agrarian policy, forest policy and entrepreneurial organization. Forest Policy and Economics, v. 8, n. 4, p. 470-484, 2006.

BROOKS, J.; WAYLEN, K.; MULDER, M. Assessing community-based conservation projects: A systematic review and multilevel analysis of attitudinal, behavioral, ecological, and economic outcomes. Environmental Evidence, v. 2, n. I, p. 2, 2013.

BULLOCK, R.; LAWLER, J. Community forestry research in Canada: A bibliometric perspective. Forest Policy and Economics, v. 59, p. 47-55, 2015.

CHEN, H.; SHIVAKOTI, G.; ZHU, T.; MADDOX, D. Livelihood Sustainability and Community Based Co-Management of Forest Resources in China: Changes and Improvement. Environmental Management, v. 49, n. I, p. 219-228, 201 I.

CHOMITZ, K.M. At loggerheads? Agricultural expansion, poverty reduction, and environment in the tropical forests. In: World Bank Research Report, 2007. 32p.

CHUANG, K.; HUANG, Y.; HO, Y. A bibliometric and citation analysis of stroke-related research in Taiwan. Scientometrics, v. 72, n. 2, p. 20I-2I2, 2007.

CLEMENT, F; AMEZAGA, J.M. Conceptualising context in institutional reforms of land and natural resource management: the case of Vietnam. International Journal of the Commons, v. 7, n. I, p. I40, 2013.

COLLEN, W.; KRAUSE, T., MUNDACA, L.; NICHOLAS, K. A. Building local institutions for national conservation programs: lessons for developing Reducing Emissions from Deforestation and Forest Degradation (REDD+) programs. Ecology and Society, v. 2I, n. 2, 2016.

COX, M.; ARNOLD, G.; VILLAMAYOR TOMÁS, S. A Review of Design Principles for Community-based Natural Resource Management. Ecology and Society, v. I5, n. 4, 2010.
CRAWFORD, S.E.S.; OSTROM, E. A Grammar of Institutions. American Political Science Review, v. 89, n. 3, p. 582-600, 1995.

CRONKLETON, P.; LARSON, A. M.; FEINTRENIE, L.; GARCIA, C.; LEVANG, P. Reframing Community Forestry to Manage the Forest-Farm Interface. Small-scale Forestry, v. I2, n. I, p. 5-I3, 2013.

CRONKLETON, P.; SAIGAL, S.; PULHIN, J. Co-management in community forestry: How the partial devolution of management rights creates challenges for forest communities. Conservation and Society, v. I0, n. 2, p. 91, 2012.

DEEGEN, P. Economics of the external and the extended orders of markets and politics and their application in forestry. Forest Policy and Economics, v. 35, p. 21-30, 2013.

DORJI, L.; WEBB, E.; SHIVAKOTI, G. Forest property rights under nationalized forest management in Bhutan. Environmental Conservation, v. 33, n. 2, p. |4|-|47, 2006.

DRACK, M. Ludwig von Bertalanffy's early system approach. Systems Research and Behavioral Science, v. 26, n. 5, p. 563-572, 2009.

DRACK, M.; WOLKENHAUER, O. System approaches of Weiss and Bertalanffy and their relevance for systems biology today. Seminars in Cancer Biology, v. 21, n. 3, p. I50-|55, 20|| .

FLEISCHMAN, F. D.; BOENNING, K.,;GARCIA-LOPEZ, G. A.; MINCEY, S.; SCHMITT-HARSH, M.; DAEDLOW, K.; LOPEZ, M. C.; BASURTO, X.; FISCHER, B.; OSTROM, E. Disturbance, Response, and Persistence in SelfOrganized Forested Communities: Analysis of Robustness and Resilience in Five Communities in Southern Indiana. Ecology and Society, v. I5, n. 4, 2010.

FLEISCHMAN, F. Understanding India's forest bureaucracy: a review. Regional Environmental Change, v. I6, n. SI, p. I53-I65, 2015

FOOD AND AGRICULTURE ORGANIZATION OF THE UNITED NATIONS - FAO. From reference levels to results reporting: REDD+ under the UNFCCC. 2018 update. Available at: http://www.fao.org/3/a-i7l63e.pdf. Accessed in: 07 agosto 2019.

FU, H.; FANG, K.; FANG, C. Characteristics of scientific impact of Resources Conservation and Recycling in the past 30 years. Resources, Conservation and Recycling, v. I37, p. $25 \mathrm{I}-259,2018$.

FU, H.; WANG, M.; HO, Y. Mapping of drinking water research: A bibliometric analysis of research output during 1992-201 I. Science of The Total Environment, v. 443, p. 757-765, 2013

GARFIELD, E. Keywords Plus: ISl's breakthrough retrieval method. Part I. Expanding your searching power on current contents on diskette. Curr. Contents, v. 32, p. 5-9, 1990. 
GATTO, P.; BOGATAJ, N. Disturbances, robustness and adaptation in forest commons: Comparative insights from two cases in the Southeastern Alps. Forest Policy and Economics, v. 58, p. 56-64, 2015.

GORDON, H. The Economic Theory of a Common-Property Resource: The Fishery. Journal of Political Economy, v. 62, n. 2, p. 124-|42, 1954.

GRAFTON, R. Governance of the Commons: A Role for the State?. Land Economics, v. 76, n. 4, p. 504, 2000.

GUARIGUATA, M. R.; CRONKLETON, P.; DUCHELLE, A. E.; ZUIDEMA, P. A. Revisiting the 'cornerstone of Amazonian conservation': a socioecological assessment of Brazil nut exploitation. Biodiversity and Conservation, v. 26, n. 9, p. 2007-2027, 2017.

GUO, L.; XU, F.; FENG, Z.; ZHANG, G. A bibliometric analysis of oyster research from I99I to 2014. Aquaculture International, v. 24, n. I, p. 327-344, 2015.

GURNEY, G.; CINNER, J.; SARTIN, J.; PRESSEY, R.; BAN, N.; MARSHALL, N.; PRABUNING, D. Participation in devolved commons management: Multiscale socioeconomic factors related to individuals' participation in community-based management of marine protected areas in Indonesia. Environmental Science \& Policy, v. 6I, p. 212-220, 2016.

HARDIN, G. The Tragedy of the Commons. Science, v. I62, n. 3859, p. I243-1248, 1968.

HESS, C., OSTROM, E. Understanding Knowledge as a Commons: From Theory to Practice. Cambridge, MA: MIT Press, 2007, 383 p.

HINKEL, J.; BOTS, P.W.G.; SCHLÜTER, M. Enhancing the Ostrom social-ecological system framework through formalization. Ecology and Society, v. 19, n. 3, 2014.

HLAING, E.E.S.; INOUE, M.; PULHIN, J.M. A Property-Rights Approach to Understanding Regulations and Practices in Community-Based Forest Management: Comparison of Three Systems in the Philippines. Small-scale Forestry, v. I2, n. 4, p. 579-596, 2013.

HOLDEN, S.; TILAHUN, M. The importance of Ostrom's Design Principles: Youth group performance in northern Ethiopia. Norwegian University of Life Sciences, 2018. 62 p.

HUANG, L.; ZHANG, Y.; GUO, Y.; ZHU, D.; PORTER, A. L. Four dimensional Science and Technology planning: A new approach based on bibliometrics and technology roadmapping. Technological Forecasting and Social Change, v. 81 , p. 39-48, 2014.

JUMBE, C.B.; ANGELSEN, A. Forest dependence and participation in CPR management: Empirical evidence from forest co-management in Malawi. Ecological Economics, v. 62, n. 3-4, p. 66I-672, 2007.
七APNIEWSKA, Z. Reading Elinor Ostrom through a Gender Perspective. Feminist Economics, v. 22, n. 4, p. I29-I5I, 2016.

LIU, X.; ZHANG, L.; HONG, S. Global biodiversity research during 1900-2009: a bibliometric analysis. Biodiversity and Conservation, v. 20, n. 4, p. 807-826, 201 I.

LOAIZA, T.; NEHREN, U.; GEROLD, G. REDD+ implementation in the Ecuadorian Amazon: Why land configuration and common-pool resources management matter. Forest Policy and Economics, v. 70, p. 67-79, 2016.

LOPEZ, M.C.; MORAN, E.F. The legacy of Elinor Ostrom and its relevance to issues of forest conservation. Current Opinion in Environmental Sustainability, v. 19, p. 47-56, 2016.

MA. Millennnium Ecosystem Assessment. Ecosystems and Human Well-Being; Biodiversity Synthesis World Resources Institute: Washington, DC, USA, 2005. I55 p.

MALESIOS, C., ARABATZIS, G., 20I2. An evaluation of forestry journals using bibliometric indices. Annals of Forest Research, v.55, n.2, p. I47-I64, 2012.

MARTÍN-LÓPEZ, B.; OTEROS-ROZAS, E.; COHENSHACHAM, E.; SANTOS-MARTÍN, F; NIETO-ROMERO, M.; CARVALHO-SANTOS, C.; GONZÁLEZ, J.A.; GARCÍA-LLORENTE, M.; KLASS, K.; GEIJZENDORFFER, I.; MONTES, C.; CRAMER, W. Ecosystem Services Supplied by Mediterranean Basin Ecosystems. In POTSCHIN, M.; HAINES-YOUNG, R.; FISH, R.; TURNER, K.; Handbook of Ecosystem Services. Eds.; Routledge: New York, 2016. p. 405-4I4.

MILUPI, I. D. A REVIEW OF COMMUNITY-BASED NATURAL RESOURCE MANAGEMENT. Applied Ecology and Environmental Research, v. 15, n. 4, p. II 2 II I43, 2017.

NABANE, N.; MATZKE, G. A gender-sensitive analysis of a community-based wildlife utilization initiative in Zimbabwe's Zambezi valley. Society \& Natural Resources, v. 10, n. 6, p. 519-535, 1997.

NIGUSSIE, Z.; TSUNEKAWA, A.; HAREGEWEYN, N.; ADGO, E.; COCHRANE, L.; FLOQUET, A.; ABELE, S. Applying Ostrom's institutional analysis and development framework to soil and water conservation activities in north-western Ethiopia. Land Use Policy, v. 7I, p. I-10, 2018.

OLSON, M. The Logic of Collective Action. Cambridge: Harvard University Press, 1965. 208 p.

OSTROM, E. A diagnostic approach for going beyond panaceas. Proceedings of the National Academy of Sciences, v. 104, n. 39, p. I5I8I-I5I87, 2007.

OSTROM, E. A General Framework for Analyzing Sustainability of Social-Ecological Systems. Science, v. 325, n. 5939, p. 419-422, 2009. 
OSTROM, E. An agenda for the study of institutions. Public Choice. v. 48, n. I, p. 3-25, 1986.

OSTROM, E. Beyond Markets and States: Polycentric Governance of Complex Economic Systems. American Economic Review, v. 100, n. 3, p. 641-672, 2010.

OSTROM, E. Governing the Commons: The Evolution of Institutions for Collective Action. Cambridge University Press, 1990. 298 p.

OSTROM, E. The Challenge of Common-Pool Resources. Environment: Science and Policy for Sustainable Development, v. 50, n. 4, p. 8-21, 2008.

OSTROM, E., DIETZ, T., DOLSAK, N., STERN, P.C., STONICH, S., WEBER, E.U., 2002. The Drama of the Commons. Committee on the Human Dimensions of Global Change, National Research Council. Washington: National Academy Press, 2002. 533 p.

OSTROM, E.; GARDNER, R.; WALKER, J. Rules, Games, and Common-Pool Resources. 1994. 386 p.

PALENCIA, C.; CASTRO, A.; GIAIOTTI, D.; STEL, F; VINET, F; FRAILE, R. Hailpad-based research: A bibliometric review. Atmospheric Research, v. 93, n. I-3, p. 664-670, 2009.

PENNISI, E., Systems Biology: Tracing Life's Circuitry. Science, v. 302, n. 565I, p. 1646-I649, 2003.

PLUMMER, R.; FITZGIBBON, J. Co-management of Natural Resources: A Proposed Framework. Environmental Management, v. 33, n. 6, 2004.

POHJANMIES, T.; TRIVIÑO, M.; LE TORTOREC, E.; MAZZIOTTA, A.; SNÄLL, T.; MÖNKKÖNEN, M. Impacts of forestry on boreal forests: An ecosystem services perspective. Ambio, v. 46, n. 7, p. 743-755, 2017.

PORRAS, I.; BARTON, D.N.; CANON-CASCANTE, A.; MIRANDA, M. Learning From 20 Years of Payments for Ecosystem Services in Costa Rica. International Institute for Environment and Development, 20I3. 76 p.

PREMRL, T.; UDOVČ, A.; BOGATAJ, N.; KRČ, J. From restitution to revival: $A$ case of commons re-establishment and restitution in Slovenia. Forest Policy and Economics, v. 59, p. 19-26, 2015.

QUINN, C.; HUBY, M.; KIWASILA, H.; LOVETT, J. Design principles and common pool resource management: An institutional approach to evaluating community management in semi-arid Tanzania. Journal of Environmental Management, v. 84, n. I, p. 100-II3, 2007.

ROMANELLI, J. P., FUJIMOTO, J. T., FERREIRA, M. D., MILANEZ, D. H. Assessing ecological restoration as a research topic using bibliometric indicators. Ecological Engineering, v. I20, p. 31 I-320, 2018.
ROY, A.K.D.; ALAM, K.; GOW, J. A review of the role of property rights and forest policies in the management of the Sundarbans Mangrove Forest in Bangladesh. Forest Policy and Economics, v. 15, p. 46-53, 2012.

ROY, A.K.D.; ALAM, K.; GOW, J. Community perceptions of state forest ownership and management: A case study of the Sundarbans Mangrove Forest in Bangladesh. Journal of Environmental Management, v. II7, p. I4I149, 2013.

SAUNDERS, F.P. The promise of common pool resource theory and the reality of commons projects. International Journal of the Commons, v. 8, n. 2, p. 636, 2014.

SCHLAGER, E., OSTROM, E. Property-rights regimes and natural resources: A conceptual analysis. Land Economics, v. 68, n. $3,249-262,1992$.

SEKHER, M. Organized participatory resource management: insights from community forestry practices in India. Forest Policy and Economics, v. 3, n. 3-4, p. I37-I54, 2001.

ŞENEL, E.; DEMIR, E. Bibliometric and Scientometric Analysis of the Articles Published in the Journal of Religion and Health Between 1975 and 2016. Journal of Religion and Health, v. 57, n. 4, p. |473-|482, 2018.

ŞENEL, E.; DEMIR, E.; ALKAN, R. M. Bibliometric analysis on global behc, et disease publications during 1980-2014: Is there a silk road in the literature? Journal of the European Academy of Dermatology and Venereology, v. 3I, n. 3, p. $518-522,2017$

SHAHABUDDIN, G.; RAO, M. Do community-conserved areas effectively conserve biological diversity? Global insights and the Indian context. Biological Conservation, v. 143, n. I2, p. 2926-2936, 2010.

SIKOR, T.; HE, J.; LESTRELIN, G. Property Rights Regimes and Natural Resources: A Conceptual Analysis Revisited. World Development, v. 93, p. 337-349, 2017.

SONG, Y.; ZHAO, T. A bibliometric analysis of global forest ecology research during 2002-20I I. SpringerPlus, v. 2, n. I, 2013.

STRAND, J. Forest Preservation Under REDD+ Schemes With Incentives Distortions. Ecological Economics, v. I54, p. 343-348, 2018.

TING, Z.; HAIYUN, C.; SHIVAKOTI, G. P.; COCHARD, R.; HOMCHA-AIM, K. Revisit to community forest in northeast of Thailand: changes in status and utilization. Environment, Development and Sustainability, v. 13, n. 2, p. $385-402,2010$

TING, Z.; SHIVAKOTI, G. P.; HAIYUN, C.; MADDOX, D. A survey-based evaluation of community-based co-management of forest resources: a case study of Baishuijiang National Natural Reserve in China. Environment, Development and Sustainability, v. I4, n. 2, p. 197-220, 201 I. 
URECH, Z.; SORG, J.; FELBER, H. Challenges for CommunityBased Forest Management in the KoloAla Site Manompana. Environmental Management, v. 5I, n.3, p. :602-6I5, 2013.

VAN ECK. N.J.; WALTMAN, L.; DEKKER, R.; VAN DEN BERG, J. A comparison of two techniques for bibliometric mapping: Multidimensional scaling and VOS. J Am Soc Inf Sci Technol, v. 6I, n. I2, p. 2405 - 24I6, 2010.

VESPA, N. I.; ZURITA, G. A.; GATTI, M. G.; BELLOCQ, M. I. Seed movement between the native forest and monoculture tree plantations in the southern Atlantic forest: A functional approach. Forest Ecology and Management, v. 430, p. I26-I33, 2018.

VOGT, J. M.; EPSTEIN, G. B.; MINCEY, S. K.; FISCHER, B. C.; MCCORD, P. Putting the "E" in SES: unpacking the ecology in the Ostrom social-ecological system framework. Ecology and Society, v. 20, n. I, 2015.

VON BERTALANFFY, L. General System Theory: Foundations, Development, Applications. Braziller: New York, 1968. 289 p.

WILKES-ALLEMANN, J.; HANEWINKEL, M.; PÜTZ, M. Forest recreation as a governance problem: four case studies from Switzerland. European Journal of Forest Research, v. 136, n. 3, p. 5II-526, 2017.
WORLD COMMISSION ON ENVIRONMENT AND DEVELOPMENT (WCED). Our Common Future. Avalilable at: https://sustainabledevelopment.un.org/ content/documents/5987our-common-future.pdf. Accessed in: 07 agosto 2019.

ZHANG, J.; YU, Q.; ZHENG, F.; LONG, C.; LU, Z.; DUAN, Z. Comparing keywords plus of WOS and author keywords: A case study of patient adherence research. Journal of the Association for Information Science and Technology, v. 67, n. 4, p. 967-972, 2015.

ZHANG, Y.; ZHANG, Y.; SHI, K.; YAO, X. Research development, current hotspots, and future directions of water research based on MODIS images: a critical review with a bibliometric analysis. Environmental Science and Pollution Research, v. 24, n. 18, p. I5226I5239, 2017.

ZHU, T.; KROTT, M.; CHEN, H. Co-management implementation in forested national reserves: Contradicting cases from China. Forest Policy and Economics, v. 38, p. 72-80, 2014. 